\title{
Nutritional evaluation of aquaculture mussels (M. galloprovincialis) from the Black Sea, Bulgaria
}

\author{
Albena MERDZHANOVA*, Diana A. DOBREVA and Stanislava GEORGIEVA \\ Department of Chemistry, Medical University of Varna, 55 Marin Drinov Str., Varna, Bulgaria
}

\begin{abstract}
In recent years black mussels are one of the most commercially important species from the Bulgarian Black Sea. The marine mollusks are valuable healthy food, low in calories and fats and high in proteins. They are a major dietary source of fat soluble pigments - astaxanthin, carotenoids and polyunsaturated fatty acids (PUFA). To our knowledge the information about the nutritional quality of mussels from the Bulgarian Black Sea waters, based on chemical composition, fat soluble pigments, cholesterol and PUFA content is very limited. The aim of the present study is to determine and compare protein, lipid, carbohydrate and energy values, fat soluble pigments, cholesterol and fatty acid composition in farmed mussels (Mytilus galloprovincialis) from the Bulgarian northern and southern parts of the Black Sea coast. The mussel samples were analyzed for lipids (Bligh \& Dyer method), crude proteins (Kjeldahl method), carbohydrates and moistures according to the AOAC (1990) methods. Fatty acids were analyzed by the GC-MS system. Fat soluble pigments and cholesterol were analyzed simultaneously by the RP-HPLC system. Lipid and protein content were found to be higher in mussels from the northern region. In accordance with the Commission Regulation (EC) No. 116/2010 all analyzed mussel samples can be classified as high in protein and low in fats and carbohydrates. The amount of cholesterol, contained in all mussel populations is significantly low, while the omega-3 (n-3) is significantly higher than the omega-6 PUFA. A portion of $100 \mathrm{~g}$ edible tissue provides $0.500 \mathrm{~g}$ more of the required amount of eicosapentaenoic acid (20:5) and docosahexaenoic acid (22:6) n-3 PUFA according to EFSA (2012). It can be concluded that the studied mussel aquaculture in the Black Sea is beneficial food for the human health and it is advisable to be part of a proper or a preventive diet of Bulgarian consumers.
\end{abstract}

Keywords: black mussels, astaxanthin, n-3 PUFA, energy value.

\section{Introduction}

Bivalve mollusks like Mytilus galloprovincialis, (Lamark, 1819) constitute a highly nutritive seafood of increasing demand on international markets. According to the official statistics of the National Agency for Fishery and Aquaculture (NAFA, Bulgaria, 2007), the Mediterranean mussel ( $M$. galloprovincialis) is the only aquaculture mollusk species in the Bulgarian Black Sea waters. Currently, there are 45 farms with a total annual production of 2520.17 tonnes in 2014 with the main part of the production for export [1]. The Black Sea favorable conditions such as salinity, water temperature and food availability increase the prospects for growing mussel culture in this area. M. galloprovincialis (Lamark, 1819) is a mass species and a bio-resource, potentially exploitable for human consumption.

Several studies report low lipid and high protein levels in the black mussels' edible part [2, 3].
Moreover, the mussels contain higher omega-3 Polyunsaturated Fatty Acids (n-3 PUFAs) with several potential cardio protective effects and antithrombotic action. Carotenoids possess high antioxidant potential and some studies report their use in preventing free-radical-initiated diseases including atherosclerosis, cataracts and age-related muscular degeneration. Beta-carotene inhibits the formation of oxidized products of LDL cholesterol, which are associated with the coronary heart disease [4]. Betacarotene is involved in the protection of the skin against the deleterious effects of sunlight. Due to these facts the interest in new sources of fat soluble pigments as beta-carotene and astaxanthin has increased in recent years. By predominantly feeding on aquatic plants, mollusks can accumulate carotenoids in their tissue. In earlier investigation on bivalve species, inhabiting the littoral region of the Black Sea, Karnaukhov et al. (1977) report that the high carotenoid content in mussels' tissue is highly

\footnotetext{
* Corresponding author: a.merdzhanova@gmail.com
} 
resistant to environmental pollution. Authors suppose that the carotenoids take part in the oxygen metabolism of mollusks [5]. To our knowledge, there are no recent studies on similar aspects for fat soluble pigments, proximate composition, FA groups and eicosapentaenoic (EPA) and docosahexaenoic (DHA) omega-3 PUFA contents in farmed mussels from the Bulgarian Black Sea coast. Therefore, the evaluation of the quality and the quantity of the mussels' nutritional components may promote their consumption and enable the consumers in making healthy food choices. When this information is available to whole populations and applied as a public health measure, the possibility for a healthier food choice may prevent several chronic diseases related to seafood consumption. Having in mind all these facts, the aim of the present study is to determine and compare proximate composition, fat soluble pigment content and FA composition of aquaculture mollusks from the Bulgarian Black Sea waters.

\section{Experimental}

\subsection{Collection of mollusk samples}

The samples were collected in autumn, 2013 from the Varna local fish markets, having as source the farms from the northern part - Kavarna (North 1) and Kranevo (North 2) and the southern part (Primorsko). The biometric characteristics as mean weight $(\mathrm{g})$ and mean length $(\mathrm{cm})$ were determined and shown in Table 1.

Table 1. Biometric characteristics of mussel samples (mean $\pm \mathrm{SD}$ )

\begin{tabular}{|l|l|l|l|}
\hline & \multicolumn{1}{|c|}{$\begin{array}{c}\text { North 1 } \\
\mathrm{n}=30\end{array}$} & \multicolumn{1}{|c|}{$\begin{array}{c}\text { North 2 } \\
\mathrm{n}=28\end{array}$} & $\begin{array}{c}\text { South } \\
\mathrm{n}=33\end{array}$ \\
\hline Mean weight & $12.0 \pm 0.5$ & $13.0 \pm 0.5$ & $11.0 \pm 0.5$ \\
Mean length & $5.5 \pm 0.5$ & $6.0 \pm 0.5$ & $4.5 \pm 0.5$ \\
\hline Habitat & \multicolumn{3}{|c|}{ Demersal } \\
\hline Food habits & \multicolumn{3}{|c}{ Herbivorous } \\
\hline
\end{tabular}

$\mathrm{n}$ - number of specimens

SD - standard deviation

All mussel farms located in ecologically nonpolluted regions along the Bulgarian Black Sea coast. The samples were immediately frozen at $-20^{\circ} \mathrm{C}$ and stored in a fridge prior to analysis.

\subsection{Sample preparation}

Thirty specimens of mussels (from each mussel farm) were used for a proximate, fatty acid and fat soluble pigments analysis. All shucked mussels were cut into small pieces and homogenized at 800 rpm for 5 minutes, using a Moulinex blender.

\subsection{Standards and reagents}

Pure solid substances of astaxanthin, betacarotene and cholesterol are HPLC-grade reagents, purchased from Sigma-Aldrich ${ }^{\mathrm{TM}}$. Fatty Acid Methyl Esters (FAME) Mix standard (SUPELCO FAME, Mix C4-C24), nonadecanoic acid and methyl ester nonadecanoic acid standards were purchased from Sigma-Aldrich ${ }^{\mathrm{TM}}$. All used chemicals were of analytical, HPLC and GC grade (Sharlau, Spain).

\subsection{Proximate composition analysis}

The test portions of homogenized mussel tissue $(2.000 \pm 0.005 \mathrm{~g})$ were dried at $105 \pm 2^{\circ} \mathrm{C}$ in an air oven for 16-18 hours to a constant weight (AOAC 950.46) [6]. The moisture was calculated as weight loss. The crude protein content was calculated by converting the nitrogen content, determined by the Kjeldahl's method [7]. The total lipids (TL) were estimated as per the Bligh and Dyer procedure (1959) and the results were presented as $\mathrm{g}$ per $100 \mathrm{~g}$ wet weight $\left(\mathrm{g} \cdot 100 \mathrm{~g}^{-1}\right.$ ww) [8]. The carbohydrates were determined according to BDS 13488:1976 [9]. The method is based on the treatment of the mussel's tissue with an alcoholic $\mathrm{KOH}$ solution and the additional acid hydrolysis of starch to glucose. The glucose quantity is determined through the oxidation with a bivalent copper from a copper reagent and is then converted into starch. The energy values were calculated by multiplying fat, protein and carbohydrate with appropriate coefficients $(4.0 \mathrm{kcal} / \mathrm{g}$ for proteins, carbohydrates; $9.0 \mathrm{kcal} / \mathrm{g}$ for lipids) [10].

\subsection{Fatty acid analysis}

The chloroform fraction was methylated by basecatalyzed transmethylation using $2 \mathrm{M} \mathrm{KOH}$ in methanol and $n$-hexane [11]. The hexane layer was separated and analyzed by GC-MS. Gas chromatography was performed by a model FOCUS Gas Chromatograph, equipped with Polaris Q MS detector (Thermo Scientific, USA). The capillary column used was a TR-5 MS, 30 m length, film thickness $0.25 \mu \mathrm{m}, 0.25 \mathrm{~mm}$ i.d. The optimum temperature gradient was $40^{\circ} \mathrm{C}$ to $280^{\circ} \mathrm{C}\left(5^{\circ} \mathrm{C} / \mathrm{min}\right)$. The injector temperature was $220^{\circ} \mathrm{C}$ and the detector temperature was $250^{\circ} \mathrm{C}$. Helium was used as a carrier gas at a flow rate of $1 \mathrm{~mL} / \mathrm{min}$. Three parallel analyses were performed for each methylated sample. Peaks were identified according to Retention Time (RT) based on available FAME mix standard (SUPELCO 37 FAME Mix C4 - C24) and mass spectra (ratio m/z) - compared to internal Data Base (Thermo Sciences Mass Library, USA). The quantitation was estimated by the method of external calibration comparing the chromatographic peak areas of the corresponding standard (SUPELCO 37 FAME Mix C4-C24). Results were expressed as a percentage of each fatty acid with respect to the total fatty acids [12]. 


\subsection{Extraction of fat soluble pigments and HPLC analysis}

The edible tissue of the mussels from the three different farms was used to evaluate its astaxanthin, beta-carotene and cholesterol content. The sample preparation was perform using the method of LopezCervantes et al. (2006) with slight modifications [13]. An aliquot of the homogenized sample $(1.000 \pm 0.005$ g) was weighed into a glass tube with a screw cap and $1 \%$ of methanolic L-ascorbic acid and $0.3 \mathrm{M}$ methanolic $\mathrm{KOH}$ were added. Six parallel samples of edible tissue from each mussel farm were prepared and subjected to saponification at $50^{\circ} \mathrm{C}$ for $30 \mathrm{~min}$. The fat soluble components of interest were extracted with two portions of $n$-hexane: dichloromethane $=2: 1$ solution. The combined extracts were evaporated under a nitrogen flow and the dry residue was dissolved in methanol: dichloromethane and injected $(20 \mu \mathrm{L})$ into the HPLC/UV/FL system. All fat soluble compounds were analyzed simultaneously using a HPLC system, equipped with an RP analytical column (Synergi Hydro-RP (80 Á, 250 x 4.6 mm; 4 $\mu \mathrm{m})$. Astaxanthin, beta-carotene and cholesterol were identified by UV detection. The mobile phase composition was ACN:MeOH: $i-\mathrm{PrOH}=75: 20: 5 \mathrm{v} / \mathrm{v}$, with the flow rate being $1 \mathrm{~mL} / \mathrm{min}$. The qualitative analysis was performed by comparing the retention times of pure substances: at $\lambda_{\max }=208 \mathrm{~nm}$ for cholesterol, at $\lambda_{\max }=450 \mathrm{~nm}$ for beta-carotene and $\lambda_{\max }=474 \mathrm{~nm}$ for astaxanthin. The quantitation was done by the method of external calibration comparing the chromatographic peak areas of the corresponding standards (Astaxanthin, Supelco; Cholecalciferol, Supelco and Beta-carotene, Supelco). The results were expressed as $\mu \mathrm{g}$ per $100 \mathrm{~g}$ wet weight $(\mu \mathrm{g} \cdot 100 \mathrm{~g}$ $\left.{ }^{1} \mathrm{WW}\right)$.

\subsection{Statistical analysis}

All analytical estimations were performed in triplicate. The results were expressed as a mean and standard deviation (mean $\pm \mathrm{SD}$ ). The obtained data was analyzed using Graph Pad Prism 5.0 software. An unpaired t-test statistical analysis was applied to estimate the differences between the analized species. Thus the comparison was made for total lipids, fat soluble vitamins and individual FA and FA groups. The differences were considered significant at $\mathrm{p}<0.05$.

\section{Results and Discussions}

\subsection{Proximate composition}

Lipids are an important energy reserve due to their high caloric value. Proteins are the most abundant chemical components in mussel tissue [12]. Carbohydrates have a structural function and are used as a long-term energy storage. Table 2 shows the proximate composition and energy value of the analyzed mollusks (mean \pm standard deviation).

Table 2. Proximate composition in mollusks tissue, in $\mathrm{g} \cdot 100 \mathrm{~g}^{-1} \mathrm{ww}$ and $\mathrm{kcal} .100^{-1} \mathrm{ww}($ mean $\pm \mathrm{SD})$

\begin{tabular}{|l|l|l|l|}
\hline & \multicolumn{1}{|c|}{ North 1 } & \multicolumn{1}{|c|}{ North 2 } & \multicolumn{1}{|c|}{ South } \\
\hline Lipid & $2.32 \pm 0.05$ & $2.51 \pm 0.06$ & $1.85 \pm 0.03^{\mathrm{c}}$ \\
\hline Protein & $17.10 \pm 0.15$ & $17.40 \pm 0.25$ & $16.80 \pm 0.1^{\mathrm{c}}$ \\
\hline $\begin{array}{l}\text { Carbo- } \\
\text { hydrate }\end{array}$ & $2.60 \pm 0.05$ & $2.55 \pm 0.05$ & $2.73 \pm 0.08^{\mathrm{c}}$ \\
\hline Moisture & $77.95 \pm 2.5$ & $77.45 \pm 2.0$ & $78.65 \pm 2.0^{\mathrm{b}, \mathrm{c}}$ \\
\hline $\begin{array}{l}\text { Energy } \\
\text { value }\end{array}$ & $99.60 \pm 2.5$ & $102.20 \pm 3.0^{\mathrm{a}}$ & $94.60 \pm 2.0^{\mathrm{c}}$ \\
\hline
\end{tabular}

${ }^{a}$ North 1 vs. North $2(\mathrm{p}<0.001)$; ${ }^{\mathrm{b}}$ North 1 vs. South $(\mathrm{p}<0.001) ;{ }^{c}$ North 2 vs. South $(\mathrm{p}<0.001)$

The assessment of the nutritional quality based on the macro nutrients' content in shellfish was conducted in accordance with Commission Regulation (EC) No 1924/2006. The nutrient values were compared with the conditions for nutrition claims regarding labelling [14].

\section{Total lipid content}

Seafood products are called "low fat" when containing no more than $3 \mathrm{~g}$ of lipid per $100 \mathrm{~g} \mathrm{ww}$. In this study the total lipid (TL) content ranged between 1.85 to $2.51 \mathrm{~g} \cdot 100^{-1} \mathrm{~g}$ ww. The highest TL is for mussels from Nord 2 region, followed by the samples from Nord 1 region, whereas mussels from Primorsko presented significantly lower values. The findings for both northern regions are higher in comparison to the data reported for TL in wild mussels and collected at other places along the Romanian Black Sea [15]. For black mussel species from different seas as the Adriatic Sea, Mar Grande of Taranto, different TL contents are reported in 2010 and 2008 [16, 17]. These patterns of temporal variability of TL in bivalve mollusks in previous studies result from several environmental factors acting simultaneously such as temperature, food availability, plankton composition and physiological factors $[2,16,17]$.

\section{Protein content}

All analysed mussel samples can be classified as "high in protein" because its amount is over $15 \%$. The observed protein levels were within the range 16.80$17.40 \%$. The farmed mussels from North 2 region showed the highest protein content which correlated with their highest TL level. The lowest protein was observed for mussels from the southern Black Sea region. According to Soumady and Asokan (2011) the protein maxima and minima levels correspond to the mussel development phases (as spawning, regression and resting cycles) [18]. Dernekbasi et al. 
(2015) and Sirbu et al. (2016) report a significantly lower protein content (7-12\%) for farmed mussels from the southern part of the Black Sea (Sinop Region) and for wild mussels from the Romanian Black Sea coast $[3,15]$.

\section{Carbohydrate content}

In this study the proteins and the lipids fluctuated in an opposite trend with respect to carbohydrates. The highest carbohydrate level $\left(2.66 \mathrm{~g} \cdot 100^{-1} \mathrm{~g}\right.$ ww $)$ was registered for the mussels from Primorsko (the southern part of the Bulgarian Black Sea). These mussels presented the lowest TL and protein content compared to other mussels from the northern Black Sea coast. Irisarri et al. (2015) report similar results for the same mussel species, cultured on the coast of Galicia (Spain) [19]. Our samples showed a higher carbohydrate amount in comparison to the wild mussels from the Romanian coast [15].

\section{Energy value}

Seafood demonstrates a variable composition of proteins and fat. The energy content is dependent on its distribution. The calculated energy value of mussels' ranges between 94.6 and $102.2 \mathrm{kcal} \cdot 100^{-1} \mathrm{~g}$ ww. Based on these results all farmed mussels can be classified as low caloric food. No data is available in literature concerning the energy values. Along the Bulgarian Black Sea coast there are wide variations of the main environmental factors with a direct impact on the accumulation of biochemical components with nutritional value. Therefore, farmed mussels from the northern and the southern Black Sea coast showed differences in their edible tissue proximate composition.

\subsection{Fatty Acid Composition}

There are wide variations and significant differences $(p<0.05)$ in the FA profiles of the mollusks population in terms of total saturated (SFA), monounsaturated (MUFA) and polyunsaturated FAs (PUFA). Traditionally bivalves are considered to be herbivores and it is assumed that phytoplankton is the main component of their diet and FA profile, respectively. However, several studies show that bivalves can use other food sources such as detritus, bacteria, micro- and mesozooplankton [20, 21]. Orban et al. [22] and Zlatanos [23] present a relative pattern PUFA $>$ SFA $>$ MUFA in the black mussel from the Adriatic coast and a local Mediterranean mussel farm. Our results are in agreement with these reported by Orban and Zlatanos. A deflection of this pattern (SFA> PUFA >MUFA) is presented by Badiu et al. for wild mussel samples from the Baia Mamaia ZonePark, Constanta (the Black Sea) and cape Galata (the Bulgarian Black Sea) [24, 25]. It is known that temperature and food availability are the two most important factors regulating the growth of the marine bivalve mollusks [26]. Table 3 presents the FA groups of the analyzed mollusks, omega-3 (n-3) and omega6 (n-6) PUFA, long chain EPA and DHA n-3 PUFA (LC n-3 PUFA) as a percentage of the total FA and $\mathrm{g} \cdot 100 \mathrm{~g}^{-1} \mathrm{wW}$ (mean \pm standard deviation) and FA ratios.

Table 3. Comparison of FA profiles in the edible tissue of black mussels (mean \pm SD)

\begin{tabular}{|c|c|c|c|}
\hline Fatty Acid & North 1 & North 2 & South \\
\hline \multicolumn{4}{|c|}{ \% of total FAs } \\
\hline$\Sigma$ SFA & $33.19 \pm 1.90$ & $31.25 \pm 1.70^{\mathrm{a}}$ & $32.10 \pm 2.00$ \\
\hline$\Sigma$ MUFA & $13.21 \pm 0.85$ & $16.25 \pm 1.0^{\mathrm{a}, \mathrm{c}}$ & $13.00 \pm 0.90$ \\
\hline$\Sigma$ PUFA & $53.60 \pm 2.80$ & $52.50 \pm 2.50$ & $54.90 \pm 2.20^{\mathrm{c}}$ \\
\hline$n-3$ & $33.05 \pm 1.95$ & $33.63 \pm 1.70$ & $35.95 \pm 2.10$ \\
\hline$n-6$ & $20.5 \pm 1.50$ & $18.87 \pm 2.0^{\mathrm{a}}$ & $18.95 \pm 1.75$ \\
\hline EPA & $4.70 \pm 0.35$ & $5.13 \pm 0.50$ & $7.05 \pm 0.68^{b}$ \\
\hline DHA & $27.40 \pm 1.55$ & $26.40 \pm 1.74^{\mathrm{a}}$ & $26.60 \pm 1.60$ \\
\hline EPA+DHA & $32.10 \pm 2.05$ & $31.53 \pm 1.90$ & $33.65 \pm 1.68^{c}$ \\
\hline$n-3 / n-6$ & $1.61 \pm 0.09$ & $1.78 \pm 0.15$ & $1.90 \pm 0.15^{\mathrm{b}}$ \\
\hline PUFA/SFA & $1.60 \pm 0.07$ & $1.68 \pm 0.10$ & $1.71 \pm 0.12^{\mathrm{b}}$ \\
\hline \multicolumn{4}{|c|}{$g \cdot 100 g^{-1} w w$} \\
\hline$\Sigma$ SFA & $0.640 \pm 0.05$ & $0.656 \pm 0.04$ & $0.472 \pm 0.03^{\mathrm{c}}$ \\
\hline$\Sigma$ MUFA & $0.254 \pm 0.02$ & $0.341 \pm 0.02$ & $0.191 \pm 0.01^{\mathrm{b}}$ \\
\hline इPUFA & $1.030 \pm 0.09$ & $1.103 \pm 0.11$ & $0.807 \pm 0.07^{\mathrm{c}}$ \\
\hline$n-3$ & $0.635 \pm 0.05$ & $0.706 \pm 0.06$ & $0.527 \pm 0.05^{\mathrm{c}}$ \\
\hline$n-6$ & $0.395 \pm 0.03$ & $0.396 \pm 0.03$ & $0.279 \pm 0.02^{\mathrm{c}}$ \\
\hline EPA & $0.090 \pm 0.02$ & $0.108 \pm 0.01^{\mathrm{a}}$ & $0.104 \pm 0.01^{b}$ \\
\hline DHA & $0.526 \pm 0.05$ & $0.554 \pm 0.04$ & $0.391 \pm 0.03^{c}$ \\
\hline EPA+DHA & $0.616 \pm 0.05$ & $0.662 \pm 0.05$ & $0.495 \pm 0.04^{\mathrm{c}}$ \\
\hline
\end{tabular}

${ }^{a}$ North 1 vs. North $2(\mathrm{p}<0.001) ;{ }^{b}$ North 1 vs. South $(\mathrm{p}<0.001) ;{ }^{\mathrm{c}}$ North $2 v s$. South $(\mathrm{p}<0.001)$

During the study period the analyzed species were exposed to essentially the same temperature regime but due to the different farm location and position in the water column, their food sources might vary. In addition, their potentially accessible food (phytoplankton, heterotrophic flagellates, ciliates, zooplankton, and detritus) has many common FAs. In this study the FA profile of all mollusks showed a considerable supplement of PUFA in tissues, while MUFAs were less-abundant. The PUFA content of the analyzed mollusks is in agreement with previous research data. Some authors determine PUFA levels ranging from $24.63 \%$ to $68.00 \%$ for black mussels from the Mediterranean, the Black and the Adriatic Sea and our results are within these levels [21, 23, 26]. Only Prato et al. [16] show a significantly lower PUFA levels for mussels from Mar Grande of Taranto (7.55-11.16\%) in comparison to our findings. Regardless of the mussel farm location all samples showed significantly higher n-3 PUFAs (62-66\% of total PUFA) compared to n-6 PUFA levels. These 
results are similar to the data presented by Badiu et al. [24] and Dernekbasi et al. [3] for the Black Sea mussels.

In the present investigation the major long-chain omega - 3 (n-3) PUFAs are eicosapentaenoic acid (EPA, C20:5n-3) and docosahexaenoic acid (DHA, 22:6 n-3). Phytoplankton, algae and other plants are at the base of the marine food chain and they are able to synthesize these unsaturated PUFAs in high quantities. In our study the DHA was found to be the dominant PUFA for all analyzed mussels regardless of the farm location. Culture mussels from North 1 region showed the highest obtained DHA values (27.4\% of total FA). All analyzed black mussels contained a significantly lower amount of EPA (4.7$7.05 \%$ of total FA). These results are similar to Zlatanos [23] and Dernekbasi et al. [3] investigations on farmed Mediterranean and Black Sea mussels. In contrast, Orban et al. [22] and Badiu et al. [24] find higher EPA than DHA levels in wild black mussels from the Adriatic, the Tyrrhenian and the Romanian Black Sea coasts. The observed deflections and variations of LC n-3 PUFA contents may be related to the type of food available and ingested by the mollusks and the conversion of EPA to DHA. Vernocchi et al. [26] suggest that the proportions of EPA and DHA are strongly influenced by the water temperature. Due to this fact the mussels from the southern region with warmer seawater showed the highest EPA and lower DHA levels compared to the samples from North 1 and 2 regions. The n-3 PUFA content in absolute amounts in $\mathrm{g} \cdot 100 \mathrm{~g}^{-1}$ wet weight provides more useful and accurate information for consumers. The European Food Safety Authority (EFSA, 2012) recommends a daily intake of 0.250 to $0.500 \mathrm{~g}$ EPA+DHA n-3 FA [27]. Considering the above the percentage values of these FA were recalculated to $\mathrm{g} \cdot 100 \mathrm{~g}^{-1}$ of mussel tissue according to FAO/INFOOD [28]. In the present study the highest EPA+DHA content for $100 \mathrm{~g}$ of edible tissue was found in mussels from the North 2 region (table 3). A $100 \mathrm{~g}$ portion of mussels ranged $0.495-0.662 \mathrm{~g}$ of EPA+DHA n-3 PUFA regardless of the mussel farm locations and provides $130 \%$ of the recommended daily intake. According to Commission Regulation (EC) No. 1924/2006 all analyzed farmed mussels can be classified as "high in omega 3 fatty acids" [14].

The $n-3 / n-6$ and PUFA/SFA ratios are used as indicators when comparing the relative nutritional values of sea foods. An increase in the human dietary n-3/n-6 PUFA ratio is essential for preventing coronary heart disease by reducing plasma lipids and the risk of cancer $[29,30]$. In the present study this ratio ranged from 1.60 to 1.90 and was found similar to earlier published results for the Black Sea mussels $[3,15,24,25]$. The recommended values of PUFA/SFA ratio by the Department of Health (1994) [31] are higher than 0.45 . In this study the PUFA/SFA ratio was found to be higher than the cut-off value in all species (Table 3 ). We can conclude that all culture mussels have a well-balanced and beneficial FA profile.

\subsection{Fat soluble pigments and cholesterol contents}

The results for astaxanthin, beta-carotene and cholesterol are expressed as an average and standard deviation (mean $\pm \mathrm{SD}$ ). The amounts of fat soluble compounds are presented in Table 4 as milligram per 100 grams wet weight $\left(\mathrm{mg} \cdot 100 \mathrm{~g}^{-1} \mathrm{ww}\right)$.

Table 4. Fat soluble pigments content in edible mollusks tissue, $\mathrm{mg} \cdot 100 \mathrm{~g}^{-1} \mathrm{Ww}($ mean $\pm \mathrm{SD})$

\begin{tabular}{|l|l|l|c|}
\hline & Cholesterol & Astaxanthin & $\begin{array}{c}\text { Beta- } \\
\text { carotene }\end{array}$ \\
\hline North 1 & $52.10 \pm 0.43$ & $0.100 \pm 0.005$ & $0.481 \pm 0.030$ \\
\hline North 2 & $53.00 \pm 0.35$ & $0.142 \pm 0.025$ & $0.221 \pm 0.018$ \\
\hline South & $53.00 \pm 0.35$ & $0.186 \pm 0.030$ & $0.110 \pm 0.015$ \\
\hline
\end{tabular}

The content of the analyzed fat soluble pigments in the fresh edible tissue of farmed mussels varied significantly among the different regions. The astaxanthin content in the South sample was found to be twice higher than in the North 1 sample. On the other hand, the North 1 sample showed almost 5 times and twice higher beta-carotene amount when compared to samples South and North 2, respectively.

In contrast to the two pigments' amounts, the cholesterol content in the mussels from all regions was found almost unchanged ( $p>0.05)$. Moreover according to Ordinance № 23/19.07.2005 consuming less than $300 \mathrm{mg}$ per day of cholesterol can help maintain normal blood cholesterol levels and can prevent future cardiovascular disease [32]. All analyzed mussel samples were characterized with low cholesterol content (RDA $<300 \mathrm{mg}$ /day, Ordinance № 23 / 19.07.2005).

The data in Table 4 are in good agreement with those published by other authors. MacDonald (29 $\mathrm{mg} \cdot 100 \mathrm{~g}^{-1} \mathrm{ww}$, green shell) and SELF Nutrition Data (28 mg·100 $\mathrm{g}^{-1} \mathrm{ww}$, blue mussel) report lower amounts of cholesterol in raw edible mussel tissue, compared to the data in the present study $[33,34]$.

Other authors report high content of betacarotene in wild black mussels, harvested in the Black Sea near Sevastopol, The Ukraine [35]. They find about $0.5 \mathrm{mg} \cdot 100 \mathrm{~g}^{-1} \mathrm{ww}$. This result is in the same range as our North 1 sample and higher, when compared to samples North 2 and South (Table 4).

The astaxanthin content of the analyzed samples is lower in comparison to the beta-carotene amount. 
Desnica et al. (2011) measure astaxanthin in 13 mussel samples and calculate its average concentration at about $15.4 \mathrm{mg} / \mathrm{kg}\left(1.5 \mathrm{mg} \cdot 100 \mathrm{~g}^{-1}\right.$ ww) [36]. This result is higher than ours. The most likely reason for this difference is an algal availability in the region - a key factor for the astaxanthin and beta-carotene production in herbivorous mollusks $[33,36]$.

\section{Conclusions}

Farmed black mussels from the Bulgarian Black Sea coast were analyzed with the aim to evaluate their nutritional quality. This preliminary study demonstrated that all analyzed specimens are low in total lipids and carbohydrates and high in proteins and PUFAs regardless of the mussel farm locations.

With regard to the excellent chemical composition, the low energy and cholesterol values, the high astaxanthin and beta- carotene content, the n3/n-6, PUFA/SFA ratios and the EPA+DHA n-3 PUFA amounts, we can conclude that culture mussel populations from the Bulgarian Black Sea coast are a very good source of the identified biologically active substances with a beneficial effect on the human health regardless of their habitat.

\section{References}

[1] *** National Strategic Plan for Fisheries and Aquaculture. 2007-2013. Ministry of Agriculture and Forestry; National Agency for Fisheries and Aquaculture.Available online:http://ec.europa.eu/

fisheries/cfp/eff/national_plans/list_of_national _strategic_plans/bulgaria_en.pdf

[2] M. Celik, S. Culha, H. Yildiz, S. Acarli, I. Celik and P. Celik, Journal of Geo Marine Sciences 43, 601-606 (2014).

[3] S. Dernekbasi, A. Oksuz, M. Celik, I. Karayucel and S. Karayucel, J. Aquac. Mar. Biol. 2, 2-7 (2015) DOI:10.15406/jamb.2015.02.00049

[4] V. Öhrvik, A. Malmborg, I. Mattisson, S. Wretling and C. Åstrand, Fish, shellfish and fish products - analysis of nutrients, LIVSMEDELS VERKET, NATIONAL FOOD AGENCY, Sweden (2012).

[5] V.N. Karnaukov, N.Y. Milovidova, and I.N. Kargopolova. Comp. Biochem. Physiol. 56 A, 189-193 (1977).

[6] *** AOAC 950.46 (1991), http://www.cem.de/ documents/pdf/ publikation/fat_analyses/ RF002.PDF

[7] *** BDS 9374: (1982)

[8] E. Bligh, and W. Dyer, Canadian Journal of Biochemistry and Physiology 37, 913-917 (1959).
[9] *** BDS 13488:1976

[10] *** FAO, Food and Nutrition, Fats and fatty acids in human nutrition Report of an expert consultation, Paper 91, FAO, (Final report). (2010).

[11] $* * *$ BDS EN ISO 5508 (2000)

[12] $* * *$ BDS EN ISO 5509 (2000)

[13] J. Lopez-Cervantes, D.I. Sanches-Machado, N.J. Rios-Vasquez, Journal of Chromatographie and Aquaculture 1105, 135-139 (2006)

[14] *** Commission Regulation (EC) No 1924/2006 Of the European Parliament and Of the Council of 20 December 2006 on nutrition and health claims made on foods.

[15] R. Sirbu, S. Paris, E. Cadar, M. Cherim, A. Mustafa, N. Lupascu, C. Erima, C. Lipsa, A. Tomescu, European Journal of Interdisciplinary Studies 4 (1), 122-128 (2016).

[16] E. Prato, A. Danieli, M. Maffia and F. Biandolino, Zoological Studies 49, 211-219 (2010).

[17] V. Ventrella, M. Pirini, A. Palgliarani, F. Trombetti, M.P. Manuzzi and A.R. Borgatti, Comparative Biochemistry and Physiology, Part B 149, 241-250 (2008).

[18] D. Soumady and S. Asocan, World Journal of Zoology 6, 360-363 (2011).

[19] J. Irisarri, M.J. Fernandez-Reiriz, U. Labarta, Aquaculture 435, 207-216 (2015).

[20] H. Turan, Y, Kaya and E. Erdem, Journal of Aquatic Food Product Technology 20, 100-107 (2011).

[21] D. Ezgeta-Balić, M. Najdek, M. Peharda and M. Blažina, Aquaculture 334-337, 89-100 (2012).

[22] E. Orban, G. Di Lena, T. Nevigato, I. Casini, A. Marzetti and R. Caproni, Food Chemistry 77, 57-65 (2002).

[23] S. Zlatanos, EJEAFC 7 (6), 3015-3019 (2008)

[24] D. Badiu, A.M. Balu, L. Barbes, R. Luque, R. Nita, M. Radu, E. Tanase and N. Rosoiu, Lipids 43, 892-841 (2008).

[25] A. Merdzhanova, D.A. Dobreva, M. Stancheva and L. Makedonski. Ovidius University Annals of Chemistry 25, 15-23 (2014).

[26] P. Vernocchia, M. MaVei, R. Lanciotti, G. Suzzi and F. Gardini, Food Control 18, 1575-1583 (2007).

[27] *** EFSA Panel on Dietetic Products, Nutrition and Allergies (NDA) (2012) scientific opinion on the tolerable upper intake level of eicosapentaenoic acid (EPA), docosahexaenoic acid (DHA) and docosapentaenoic acid (DPA). EFSA J. 10, 2815-2863. 
[28] *** FAO/INFOODS Guidelines (2012) FAO/INFOODS Guidelines for Converting Units, Denominators and Expressions, version 1.0. FAO, Rome.

[29] P. Kris - Etherton, W. Harris., L. Appel, Arterioscler Thromb Vasc Biol, 23, 20-30 (2003), http://www.atvbaha.org.

[30] A. Simopoulos and L. Cleland, World Rev Nutr. Diet. Basel, Karger, 92, 1-22 (2003).

[31] *** Department of Health, Nutritional aspects of cardiovascular disease: Health and social subsects. HMSO, London (1994)

[32] *** Ordinance № $23 / 19.07 .2005$ on the physiological feeding of population http://bg.wikipedia.org/ wiki /Физиологични _норми_за_хранене\#cite_note-echo-9
[33] G. MacDonald, Report, MacDonald and Associates Ltd, Nelson (2010).

[34] *** The Self Nutrition Data, 2014, http://nutritiondata. self.com/facts/finfish-andshellfish-products/4186/2

[35] N.V. Posleslova and M.V. Nekhoroshev, Ekologiya Morya 124, 62-66 (2003)

[36] N. Desnica, S. Jensen, G.G. Pórarinsdóttir, J.Ó. Jónsson, H.G. Kristinsson and H. Gunnlaugsdóttir, Icelandic Food and Biotech, Report Summary, 2011. Available online: http://www.matis.is/media/matis /utgafa/44-11Gaedakraekingur.pdf

Received: 26 April 2016 Received in revised form: 11 May 2016 Accepted: 12 May 2016 